\title{
EFFECTS OF KAYAKING ON MOTOR SKILLS IN CHILDREN AND ADOLESCENTS WITH DOWN SYNDROME
}

\author{
EFEITOS DA CANOAGEM NAS HABILIDADES MOTORAS DE CRIANÇASEADOLESCENTES COM \\ SÍNDROMEDEDOWN
}

Original Articie

ARTIGO ORIGINAL

Artículo Original

\section{EFECTOS DE CANOA EN LAS HABILIDADES MOTORAS DE NIÑOS Y ADOLESCENTES COM SÍNDROMEDEDOWN}

\begin{abstract}
Natanael Pereira Barros ${ }^{1}$ (DD (Physical Education Professional) Débora de Souza Araújo' (ID (Physical Education Professional) Elionaldo Bringel de Lima' (D) (Physical Education Professional) laraildo Pereira de Carvalho' (ID) (Physical Education Professional) Samuel da Silva Lima' (D) (Physical Education Professional) Leonardo Gasgues Trevisan Costa' (ID (Physical Education Professional)

1. Universidade Federal do Vale do São Francisco (UNIVASF), Petrolina, PE, Brazil.
\end{abstract}

\section{Correspondence:}

Natanael Pereira Barros.

Av. José de Sá Maniçoba, S/N, Centro,

Petrolina, PE, Brazil. 56320-050.

barrosnatan@yahoo.com.br

\begin{abstract}
Introdução: A síndrome de Down (SD) é uma afecção genética que se caracteriza por distribuição numérica inadequada no pareamento cromossômico, com material genético extra relacionado com o par 21 que leva a alterações que afetam o desenvolvimento de diversos componentes motores. Objetivos: Analisar os efeitos do treinamento de canoagem durante oito semanas sobre as habilidades motoras grossas em crianças e adolescentes com SD. Métodos: Sete indivíduos com SD (10,8 \pm 2 anos), quatro do sexo masculino e três do sexo feminino participaram do estudo. Para avaliar as habilidades motoras grossas, empregou-se a bateria de Teste de Coordenação Corporal para Crianças (Körperkoordination Test für Kinder, KTK). O teste de Wilcoxon foi usado para comparar os valores de habilidades motoras grossas antes e depois do KTK e o teste de Mann-Whitney foi usado para comparar os indivíduos por sexo. O tamanho do efeito foi calculado pela escala de Cohen (1977) e nível de significância de $p<0,05$ foi adotado. Resultados: Os indivíduos apresentaram resultados estatisticamente significativos em todas as tarefas do teste de coordenação motora grossa e o efeito produzido pela intervenção foi moderado. Conclusão: Conclui-se que oito semanas de treinamento de canoagem são suficientes para produzir desenvolvimento das habilidades motoras grossas de crianças e adolescentes com Síndrome de Down. Nível de Evidência IV; Série de casos.
\end{abstract}

Descritores: Síndrome de Down; Canoagem; Habilidades motoras.

\section{RESUMO}

Introduction: Down syndrome (DS) is a genetic condition characterized by an inadequate numerical distribution in chromosome pairing, with extra genetic material related to pair 21 leading to alterations that affect the development of several motor components. Objective: To analyze the effects of kayak training for eight weeks on the gross motor skills of children and adolescents with DS. Methods: Seven individuals with DS (10.8 2 2years), four males and threefemales, participated in the study. The Body Coordination Test for Children (Körperkoordination Test für Kinder, KTK) battery was used to assess gross motor skills. The Wilcoxon test was used to compare pre- and post-KTK gross motor skill values, and the Mann-Whitney test to compare subjects by sex. Effect size was calculated using Cohen's scale (1977) and a significance level of $p<0.05$ was adopted. Results: The subjects presented statistically significant results in all tasks of the gross motor coordination test, and the effect produced by the intervention was moderate. Conclusion: It can be concluded that eight weeks of kayak training are sufficient to produce a development in the gross motor skills of children and adolescents with Down syndrome. Level of Evidence IV; Case series.

Keywords: Down syndrome; Canoeing; Motor skills.

\section{RESUMEN}

Introducción: El síndrome de Down (SD) es una afección genética que se caracteriza por una distribución numérica inadecuada en la formación de pares cromosómicos, con material genético adicional relacionado con el par 21 quelleva a cambios que afectan el desarrollo de varios componentes motores. Objetivos: Analizar los efectos del entrenamiento en canoa durante ocho semanas sobre las habilidades motoras gruesas de niños y adolescentes con SD. Métodos: Siete individuos con SD (10,8 \pm 2 años), cuatro del sexo masculino y tres del sexo femenino participaron en el estudio. Para evaluar las habilidades motoras gruesas, se utilizó la batería de la Prueba de Coordinación Corporal para Niños (Körperkoordination Test für Kinder, KTK). La prueba de Wilcoxon se usó para comparar los valores de las habilidades motoras gruesas antes y después de KTKy la prueba de Mann-Whitney se usó para comparar individuos por sexo. El tamaño del efecto se calculó mediante la escala de Cohen (1977) y se adoptó un nivel de significancia de $p<0,05$. Resultados: Los individuos presentaron resultados estadísticamente significativos en todas las tareas de la prueba de coordinación motora gruesa y el efecto producido por la intervención fue moderado. Conclusión: Se concluye que ocho semanas de entrenamiento en canoa son suficientes para producir el desarrollo de las habilidades motoras gruesas de niños y adolescentes con síndrome de Down. Nivel de evidencia IV; Series de casos.

Descriptores: Síndrome de Down; Canoa; Habilidades motoras. 


\section{INTRODUCTION}

Gross motor skills can be defined as skills that use large muscle groups, such as walking, hopping, throwing, jumping, crawling, rolling, and others, ${ }^{1}$ and their development serves as an important tool to promote the execution and maintenance of coordinated body movements, ${ }^{2}$ in view of the fact that gross motor deficits are reflected in low proficiency in more complex motor tasks. In addition, this disorder can also influence children's affective social behaviors, having a negative impact on self-esteem and motivation to engage in physical activity. ${ }^{3}$

Down syndrome (DS) is a genetic condition characterized by an inadequate distribution in chromosomal pairing, which presents extra genetic material related to pair $21 .{ }^{4}$ This entails characteristics associated with trisomy, such as intellectual disability, ligament laxity, muscle hypotonia and motor development deficits, causing a delay in the attainment of motor milestones related to gross motor skills when compared to their peers without disabilities, ${ }^{5,6}$ compromising the performance of functional activities of daily living.?

To that end, research has been carried out in order to promote gains in the development of gross motor skills in children and adolescents with DS through participation in systematized physical activity. ${ }^{8}$ In a randomized clinical trial ${ }^{9}$ with an intervention program composed of physical exercises on unstable surfaces measuring the body balance of adolescents with DS, the authors observed an increase in body balance values when comparing the intervention group with the control group. According to the above, it appears that training on unstable surfaces has a positive relationship with the motor skills of subjects with DS.

Kayaking as a sport takes place on an unstable surface, providing sensory-motor, muscle strength and endurance stimuli, postural stabilization and balance reactions, ${ }^{10}$ since to remain in position inside the kayak and manage to execute vessel propulsion movements, several compensatory adjustments are required, ${ }^{11}$ with considerable potential to develop physical abilities and motor coordination. ${ }^{12}$

However, no studies investigating the relationship between kayaking and gross motor skills of children and adolescents with DS were found in the literature. Accordingly, the objective of this research project was to analyze the effects of an 8-week kayaking intervention program on the gross motor skills of children and adolescents with DS. The performance of the subjects categorized by sex was also analyzed.

\section{MATERIALS AND METHODS}

Sixteen children and adolescents of both sexes aged between six and 14 years with DS participated in this study initially. Of these, eight were excluded due to failure to complete the pre-test assessments, and one subject dropped out during the intervention program. Therefore, the study was carried out with seven individuals with DS $(10.8 \pm 2$ years), four of whom were male and three female, enrolled in schools in Petrolina - PE (state of Pernambuco) and Juazeiro - BA (state of Bahia).

As inclusion criteria, subjects needed to submit a report with a diagnosis of DS, be between eight and 14 years of age at the time of the assessments, and the Informed Consent Form (ICF) had to be signed by the parents, with assent given by the children. Exclusion criteria were class attendance below 75\%, injury or pathology that prevented the subject from continuing to participate in the intervention, or withdrawal of the consent or assent form at any time.

Regarding ethical aspects, the project was approved by the Committee of Ethics and Deontology in Studies and Research of Universidade Federal do Vale do São Francisco (UNIVASF) under number 80075917.2.0000.5196, in compliance with all regulations pertaining to research with human beings.

\section{Procedures}

The subjects were assessed before the kayaking lessons and after the intervention period. To characterize the sample, the subjects'body weight and height were measured for subsequent body mass index calculation. A Balmak mechanical scale (model 104A) with 100 gram accuracy was used to measure body weight. Height was determined by means of a metal stadiometer coupled to the scale with $0.1 \mathrm{~cm}$ precision (Balmak Ltda, Santa Barbara d'Oeste, Brazil). Participants were assessed barefoot and wearing clothing suitable for physical activity. Measurements were taken at the Biomechanics Laboratory of Universidade Federal do Vale do São Francisco - Petrolina, PE.

To assess gross motor skills, we used the Body Coordination Test for Children ${ }^{13}$ battery, which consisted of the performance of four motor tasks: a. Backward walking balance: the subject had three attempts to walk backwards along a beam of different widths $(6 \mathrm{~cm}, 4.5 \mathrm{~cm}, 3 \mathrm{~cm})$ without touching the ground. If the individual touched the ground, he or she would return to the platform at the start and make a new attempt. Each step taken by the subject on the beam was equivalent to one point, and subjects could not exceed eight points on each beam;

b. Hopping for Height: consisted of one-legged hopping over one or more $5 \mathrm{~cm}$-thick foam blocks stacked one on top of another. Each time the subject managed to hop over the block, he or she was awarded three points at the first attempt, two points at the second attempt, and one point at the third attempt, and a foam block was added after each successful hop, up to a limit of 12 blocks. Hopping was performed on the right leg first, followed by the left leg;

c. Jumping Sideways: the subject was instructed to jump from side to side on a wooden platform (length $60 \mathrm{~cm}$, width $50 \mathrm{~cm}$ ) with a dividing slat in the middle, using both feet at the same time, as fast as possible, for 15 seconds. Each subject was entitled to two attempts. Each jump was worth one point;

d. Moving Sideways: Consists of moving around on two wooden platforms (length $25 \mathrm{~cm}$, width $25 \mathrm{~cm}$ and height $5 \mathrm{~cm}$ ) duly placed next to each other on which the individual was supposed to stand. Two 20-second attempts were made, and the number of moves made during the 20 seconds were added up.

The subjects had their scores added up at the end of each task and a numerical value was generated from the score obtained in the task according to chronological age. At the end, the scores of the four tasks were added up to obtain the overall motor quotient of each subject, and to classify subjects as follows: very good coordination, good coordination, normal coordination, coordination disorder, and insufficient coordination. ${ }^{13}$

\section{Intervention}

The kayaking classes took place in the semi-Olympic pool $(25 \mathrm{~m})$ of the UNIVASF Physical Education Board and lasted for eight weeks, held twice a week with a duration of 40 minutes each and a maximum of two students per session. To carry out the activities, we used kayaks designed for tourism (Brudden ${ }^{\circledR}$ ), paddles consisting of an aluminum shaft with polystyrene paddle blades, life jackets approved by the Brazilian Navy, and recreational materials (balls, bladders, floats, buoys, and others).

The training sessions were delivered by the principal investigator with the assistance of two monitors, and lesson planning (Table 1) was prepared and supervised by a Physical Education teacher with technical training in paracanoe, certified by the Brazilian Canoeing Confederation (Confederação Brasileira de Canoagem).

\section{Statistical analysis}

The Shapiro-Wilk test for normality was adopted initially for statistical analysis. After confirming nonparametric distribution of the data, the 
Table 1. Presentation of the content and objectives of the intervention protocol.

\begin{tabular}{|c|c|c|}
\hline & & Demonstrative table \\
\hline Lesson & Objective & Activity \\
\hline \multirow{4}{*}{1} & \multirow{4}{*}{$\begin{array}{l}\text { Familiarize the } \\
\text { student with } \\
\text { the water }\end{array}$} & Moving around at the edge of the pool \\
\hline & & Poolside tag \\
\hline & & $\begin{array}{l}\text { Moving around the entire poolside area } \\
\text { with the teacher's assistance }\end{array}$ \\
\hline & & $\begin{array}{l}\text { Recreational games in the pool (cartwheels, } \\
\text { ball games, human chain) }\end{array}$ \\
\hline \multirow{5}{*}{2} & \multirow{5}{*}{$\begin{array}{l}\text { Familiarize the } \\
\text { student with } \\
\text { the kayaking } \\
\text { materials and } \\
\text { the water } \\
\text { environment }\end{array}$} & Getting in and out of the kayak on land \\
\hline & & Getting in and out of the kayak in the water \\
\hline & & $\begin{array}{l}\text { Paddling movements outside the } \\
\text { kayak, in the upright position }\end{array}$ \\
\hline & & $\begin{array}{l}\text { Paddling movements using the paddle } \\
\text { while seated at the edge of the pool }\end{array}$ \\
\hline & & $\begin{array}{l}\text { Paddling movements in the kayak using } \\
\text { the hands to provide propulsion }\end{array}$ \\
\hline \multirow{5}{*}{3} & \multirow{5}{*}{$\begin{array}{c}\text { Develop } \\
\text { paddling skills }\end{array}$} & Forward propulsion movements with the paddle \\
\hline & & Backward propulsion movements with the paddle \\
\hline & & $\begin{array}{l}\text { Propulsion movements alternating } \\
\text { the depth of the paddle blades }\end{array}$ \\
\hline & & Propulsion movements alternating paddling speed \\
\hline & & Free paddling \\
\hline \multirow{4}{*}{$4,6,15$} & \multirow{4}{*}{$\begin{array}{l}\text { Get the } \\
\text { student used } \\
\text { to paddling } \\
\text { techniques }\end{array}$} & $\begin{array}{c}\text { Paddle around objects positioned around } \\
\text { the pool (balls, buoys, floats) }\end{array}$ \\
\hline & & $\begin{array}{c}\text { Paddle and collect objects positioned } \\
\text { around the pool (balls, buoys, floats) }\end{array}$ \\
\hline & & $\begin{array}{l}\text { Paddle and collect objects positioned around } \\
\text { the pool in the shortest time possible }\end{array}$ \\
\hline & & Free paddling for 10 minutes \\
\hline \multirow{6}{*}{$5,7,12$} & \multirow{6}{*}{$\begin{array}{c}\text { Develop kayak } \\
\text { movement } \\
\text { skills }\end{array}$} & $\begin{array}{l}\text { Push a dolphin-shaped inflatable buoy } \\
\text { from one side to the other }\end{array}$ \\
\hline & & $\begin{array}{l}\text { Push a dolphin-shaped inflatable buoy along } \\
\text { while paddling round obstacles positioned } \\
\text { around the pool (balls, buoys, floats) }\end{array}$ \\
\hline & & $\begin{array}{l}\text { Fetch the dolphin from the other side of the } \\
\text { pool and bring it to the opposite side }\end{array}$ \\
\hline & & $\begin{array}{l}\text { Collect the rubber ducks positioned around } \\
\text { the pool and leave them all together }\end{array}$ \\
\hline & & $\begin{array}{l}\text { Take the dolphin and the ducks } \\
\text { to the edge of the pool }\end{array}$ \\
\hline & & Paddling with the hands for 5 minutes. \\
\hline \multirow{4}{*}{$8,10,13$} & \multirow{4}{*}{$\begin{array}{c}\text { Improve } \\
\text { stabilization } \\
\text { while paddling }\end{array}$} & $\begin{array}{l}\text { Bowling in the kayak: paddle from one edge } \\
\text { to the other with a ball, and knock down the } \\
\text { pins piled up at the edge of the pool }\end{array}$ \\
\hline & & $\begin{array}{l}\text { Taking shots at the basket from the kayak: paddle from } \\
\text { one side to the other with a ball and throw the ball } \\
\text { through the basket positioned at the edge of the pool }\end{array}$ \\
\hline & & Kayak tag \\
\hline & & Free paddling for 5 minutes \\
\hline \multirow{3}{*}{$9,11,14,16$} & \multirow{3}{*}{$\begin{array}{l}\text { Develop } \\
\text { paddling } \\
\text { techniques }\end{array}$} & Paddle in pairs around the entire area of the pool \\
\hline & & $\begin{array}{l}\text { Kayak race from one edge of the pool to the } \\
\text { other without hitting the obstacles spread } \\
\text { along the route (balls, buoys, floats); }\end{array}$ \\
\hline & & $\begin{array}{l}\text { Relay: bring as many balls positioned at one } \\
\text { side of the pool as you can in the shortest } \\
\text { time possible (one ball at a time); }\end{array}$ \\
\hline
\end{tabular}

Wilcoxon test was used to compare gross motor skill values obtained in the period before and after the 8-week intervention program. The Mann-Whitney test was used to compare values between boys and girls, while effect size was measured by the Cohen ${ }^{14}$ scale, which ranks effect as small $(0.2<0.5)$, medium $(0.5<0.8)$ or large $(\geq 0.8)$. SPSS v.22 software was used for all the analyses and the significance level was $p<0.05$.

\section{RESULTS}

This investigation is the first study to analyze the effects of a kayaking intervention protocol on the gross motor skills of children and adolescents with DS. The sample characterization data (central tendency and dispersion) on body weight, height and body mass index are presented in Table 2.

According to Table 2, there was an increase in the subjects' height and body weight values, whereas a statistically significant difference was only identified in height when pre- and post-test times were compared.

Regarding gross motor skills, statistically significant differences were found in all KTK tasks: balance beam (pre Md: 1; post: 4; $f^{2}=0.6$ ); hopping for height (pre Md: 6; post: 9; $f^{2}=0.2$ ), jumping sideways (pre Md: 16; post: $17 ; f^{2}=0.7$ ), and moving sideways (pre Md: 15 ; post: $20 ; f^{2}=0.5$ ) Regarding the overall motor coefficient, no statistically significant differences were found, and the subjects had lower median values in the pre- (md: 62) and post-intervention period (md: 61) comparison. (Table 3)

In analyzing the effects categorized by sex (Figure 1), we can see that the boys had an increase in median values after the intervention period in the balance beam $\left(\Delta=+7.5 ; f^{2}=0.7\right)$, hopping for height $(\Delta=+0.5$; $\left.f^{2}=0.1\right)$, jumping sideways $\left(\Delta=+7.5 ; f^{2}=0.6\right)$, and moving sideways $\left(\Delta=+5.5 ; f^{2}=0.4\right)$ motor tasks.

The girls also showed an increase in median values after the intervention period, with the exception of jumping sideways, with an increase in balance beam backward walking $\left(\Delta=+4.0 ; f^{2}=0.9\right)$, hopping for height $\left(\Delta=+3.0 ; f^{2}=1.4\right)$ and moving sideways $\left(\Delta=+3.0 ; f^{2}=2.1\right)$. No statistically significant differences were found between boys and girls in the median values obtained in the motor tasks.

According to the criteria established to classify the level of motor coordination as very good coordination, good coordination, normal coordination, coordination disorder and insufficient coordination, ${ }^{13}$ considering the scores of the sample in the overall motor quotient, $100 \%$ of subjects were classified as having insufficient motor coordination. After the 8-week kayaking intervention period, $28 \%$ of subjects improved their classification for impaired motor coordination, while the majority (72\%) maintained the same classification.

\section{DISCUSSION}

Height, weight and BMI data were used to characterize the sample. Considering the time interval of the intervention and the age group of the sample, statistically significant differences were found for height between the pre and post-test time points.

Table 2. Central tendency (median) and dispersion (quartiles 25 and 75) values referring to height, body weight and BMI. * Significant difference.

\begin{tabular}{c|c|c|c|c|c|c|c|c}
\hline \multicolumn{7}{|c}{ Characterization of the subjects } \\
\hline & $\mathbf{N}$ & \multicolumn{3}{|c|}{ Pre-test } & \multicolumn{3}{c|}{ Post-test } & p \\
\hline & & $25^{\circ}$ & Md & $75^{\circ}$ & $25^{\circ}$ & md & $75^{\circ}$ & \\
\hline Height (m) & 7 & 1.29 & 1.34 & 1.57 & 1.30 & 1.36 & 1.58 & $0.02^{*}$ \\
\hline Weight (kg) & 7 & 28.8 & 45.5 & 70.8 & 29.9 & 45.4 & 71.4 & 0.35 \\
\hline BMI & 7 & 17.4 & 25.3 & 26.7 & 17.4 & 24.5 & 26.5 & 0.40 \\
\hline
\end{tabular}

Table 3. Comparison of the central tendency (median) and dispersion (quartiles 25 and 75) values, obtained by the sample in the Body Coordination Test for Children (KTK).

\begin{tabular}{c|c|c|c|c|c|c|c|c|c}
\hline & & \multicolumn{3}{|c|}{ Pre } & \multicolumn{3}{c|}{ Post } & & \\
\hline & $\mathbf{N}$ & $\mathbf{2 5}$ & $\mathbf{M d}$ & $\mathbf{7 5}$ & $\mathbf{2 5}$ & $\mathbf{M d}$ & $\mathbf{7 5}$ & $\mathbf{f}^{\mathbf{2}}$ & $\mathbf{P}$ \\
\hline $\mathrm{BB}$ & 7 & 0 & 1 & 4 & 0 & 4 & 16 & 0.60 & $0.04^{*}$ \\
\hline $\mathrm{HH}$ & 7 & 3 & 6 & 13 & 6 & 9 & 14 & 0.24 & $0.04^{*}$ \\
\hline JS & 7 & 8 & 16 & 19 & 16 & 17 & 25 & 0.74 & $0.02^{*}$ \\
\hline MS & 7 & 15 & 15 & 17 & 16 & 20 & 22 & 0.58 & $0.01^{*}$ \\
\hline OMG & 7 & 52 & 62 & 64 & 55 & 61 & 72 & 0.53 & 0.12 \\
\hline
\end{tabular}

BB: Balance beam; HH: Hopping for height; JS: Jumping sideways; MS: Moving sideways; OMQ: Overall moto quotient. Min: Minimum; Max: Maximum. * Significant difference. 


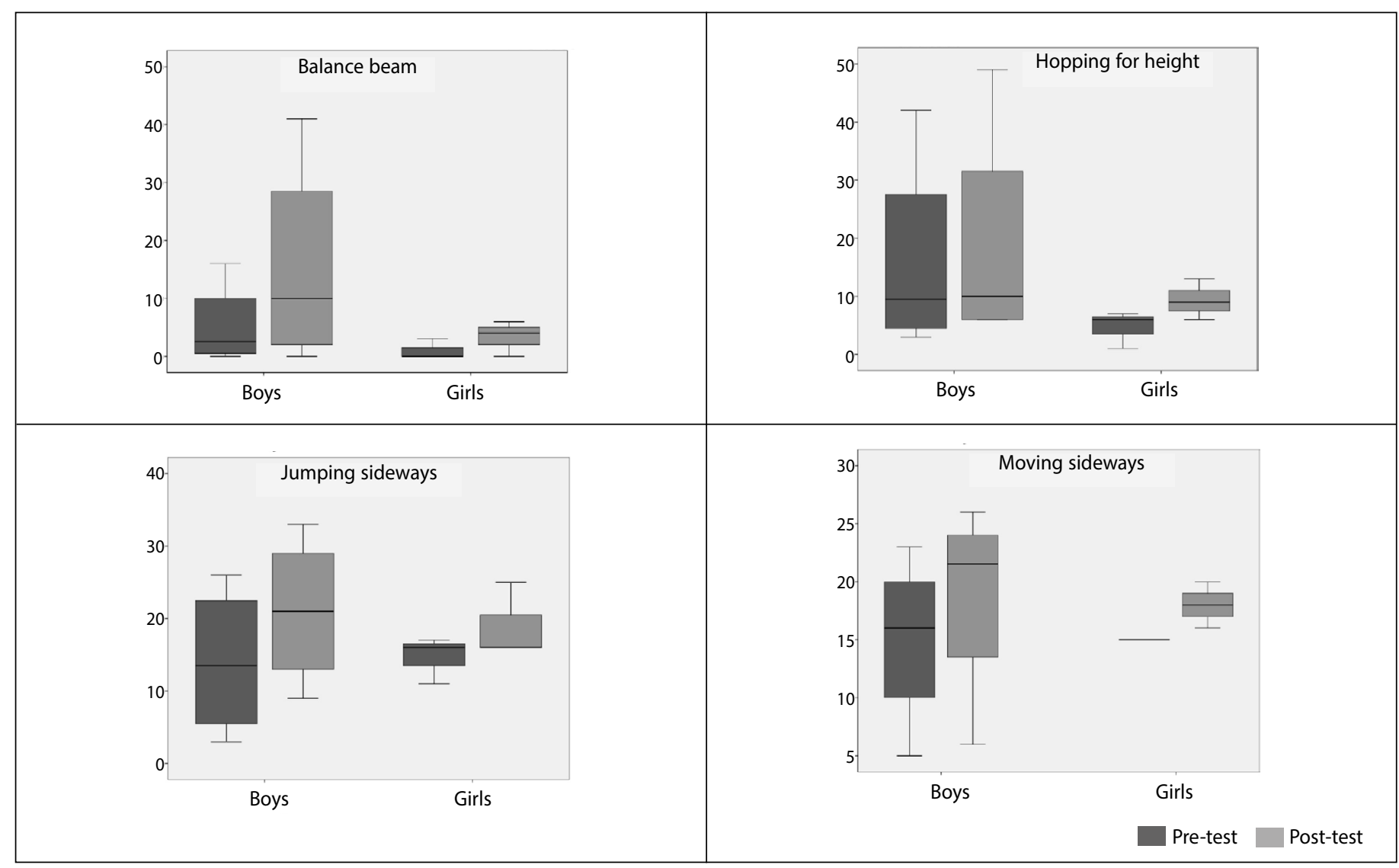

Figure 1. Comparison of values obtained by boys and girls in the motor tasks during the pre- and post-test periods.

Most subjects with DS have difficulty walking, jumping and balancing due to alterations caused by chromosome 21 trisomy and the lack of motor stimuli throughout life..$^{15}$ In this respect, environmental conditions can promote neural adaptations, ${ }_{1}^{16}$ which gradually enable the acquisition of motor skills.

Several studies have shown that children and adolescents with DS have a low level of gross motor skills ${ }^{17-19}$ from the first years of life. ${ }^{20}$

In a study ${ }^{21}$ comparing the gross motor skills of children with DS, children with atypical cognitive development, and children with typical development in locomotor skills activities and in object control tasks, the authors identified that children with DS have lower gross motor skill performance values when compared to the studied groups. In another study, ${ }^{22}$ when analyzing the differences in gross motor skills between children with intellectual disabilities and typical development, the authors found that the motor proficiency of children with intellectual disabilities is significantly reduced when compared to their peers without disabilities.

Most people with DS have motor disorders due to alterations in the central nervous system (reduced brain size and volume, lower neural density, low synaptic density and delayed myelination), musculoskeletal characteristics (muscle hypotonia, joint laxity, body proportion) and health problems (cardiovascular abnormalities, respiratory diseases, sensory deficits, hormonal imbalance, and epilepsy). ${ }^{23}$ Studies have revealed reduced size of the frontal, occipital and temporal lobes, with lower volume of the hippocampus and cerebellum, which directly influence the performance of voluntary movements, gait, body balance, motor coordination and laterality. ${ }^{19}$

However, the central nervous system is not a rigid structure, but rather a structure with considerable adaptability and the possibility of modifying some of its functional and morphological properties in response to changes in the environment. ${ }^{24}$ Therefore, intervention programs can promote an improvement in the human development of children and adolescents with DS.
The results of this study demonstrated that kayak training brought about an increase in the values of gross motor skills in all motor tasks assessed through the Body Coordination Test for Children ${ }^{13}$ battery, when compared to the pre- and post-intervention time points. These positive effects may be related to the demands of the sport, as it requires postural control in the sitting position and involves several challenges related to the specific sensory-motor system of postural control, since the sitting position requires continuous body balance adjustments due to the movements of the upper limbs of the body, the kayak, and the paddle in the water, as well as the upper limbs and paddle in the air. ${ }^{25}$

The effects found in the study are consistent with the literature, which indicates that physical activity intervention programs have positive effects on the motor development of children and adolescents with DS. ${ }^{26,27}$ In another study, ${ }^{28}$ when analyzing the effects of an equine therapy intervention on the gross motor coordination of 41 children with DS, divided into a control group and an experimental group, the scores of subjects who participated in the intervention showed a higher numerical value of the motor quotient when compared to subjects who did not participate in the intervention.

Regarding the performance of children and adolescents with DS in this particular study, categorized by sex, it can be noted that boys achieved higher statistically significant median values in all the motor tasks. Girls, on the other hand, showed a statistically significant increase in motor tasks, with the exception of sideways jumps. When comparing the motor proficiency of boys and girls, we observed that boys achieved higher values in all motor tasks.

These findings are consistent with the literature, which when analyzing the motor skills of boys and girls with DS, found higher scores in the motor tasks performed by boys when compared to girls. 29,30

Regarding the classification of motor coordination, the results of this research study corroborate previous studies $5,2,20,22$ by classifying all 
subjects with insufficient motor coordination at the pre-test time point and $28 \%$ with motor coordination disorders after the intervention period.

An important observation point in this research project is related to the effect produced by the intervention. In just eight weeks, the study produced moderate positive effects in the sample $\left(f^{2}=0.5<0.7\right)$, promoting an improvement in the motor coordination classification of $28 \%$ of subjects.

The lack of studies covering the relationship between gross motor skills and kayaking makes it difficult to reach a broader understanding of the topic. Thus, it is suggested that further studies be carried out with a larger sample size and longer intervention time, expanding the potential effect of the kayak training protocol on the gross motor skills of children and adolescents with DS.

\section{CONCLUSIONS}

This investigation is the first study to assess the effects of kayaking on the gross motor coordination of children and adolescents with DS.
The results demonstrated positive effects on motor tasks related to the gross motor proficiency of children and adolescents with DS, after the intervention period consisting of kayaking lessons.

Thus, we can conclude that the kayak training protocol adopted during this study, lasting eight weeks, brought about an improvement in the performance of gross motor skills in the sample group of this study. Accordingly, to assist in the human development of this population, it is suggested that the sport be used by professionals who work with people with DS.

\section{ACKNOWLEDGMENTS}

We are grateful to the Confederação Brasileira de Canoagem-CBCa for their assistance in the development of kayaking/canoeing in the cities of Juazeiro-BA and Petrolina-PE.

All authors declare no potential conflict of interest related to this article

AUTHORS' CONTRIBUTIONS: Each author made significant individual contributions to this manuscript. NPB: writing, intervention, data analysis and review; DSA: review, data collection and intervention; EBL, IPC, and SSL: intervention and data collection; LGTC: statistical analysis, writing and review. All authors approved the final version of the manuscript.

\section{REFERENCES}

1. Magill RA. Aprendizagem e controle motor: conceitos e aplicações. 8. ed. Phorte: São Paulo, 2011

2. Lestari I, Ratnaningsih T. The effects of modified games on the development of gross motor skill in preschoolers. Int J Evaluation Res Educ. 2016;5(3):216-20.

3. Catenassi FZ, Marques I, Bastos CB, Basso L. Relação entre índice de massa corporal e habilidade motora grossa em crianças de quatro a seis anos. Rev Bras Med Esporte. 2007;13(4):227-30.

4. Costa LT, Duarte E, Gorla Jl. Síndrome de Down: crescimento, maturação e atividade física. 1. ed. São Paulo: Phorte; 2017.

5. Bonomo LM, Rossetti CB. Aspectos percepto-motores e cognitivos do desenvolvimento de crianças com Síndrome de Down. Rev Bras Crescimento Desenvolvimento Hum. São Paulo. 2010;20(3):723-34.

6. Borssatti F, dos Anjos FB, Ribas DI. Efeitos dos exercícios de força muscular na marcha de indivíduos portadores de Síndrome de Down. Fisioter Mov. 2013;26(2):329-35.

7. Leite JC, Neves JC, Vitor LG, Fujisawa DS. Controle postural em crianças com Síndrome de Down: avaliação do Equilíbrio e da Mobilidade Funcional. Rev Bras Educ Espec. 2018;24(2):173-82.

8. Gupta S, Rao BK, Kumaran SD. Effect of strength and balance training in children with Down's syndrome: a randomized controlled trial. Clin Rehabil. 2011;25(5):425-32.

9. Jankowicz-Szymanska A, Mikolajczyk E, Wojtanowski W. The effect of physical training on static balance in young people with intellectual disability. Res Devel Disabilities. 2012;33(2):675-81.

10. Taylor LP, Mcgruder JE. The meaning of sea kayaking for persons with spinal cord injuries. Am J Occup Ther. 1996;50(1):39-46

11. Lemos LF, Teixeira CS, Mota CB. Lombalgia e o equilíbrio corporal de atletas da seleção brasileira feminina de canoagem velocidade. Rev Bras Cineantropom Desempenho Hum. 2010;12(6):457-63.

12. Bjerkefors A, Thorstensson A. Effects of kayak ergometer training on motor performance in paraplegics. Int J Sports Med. 2006;27(10):824-9

13. Gorla Jl, Araújo PF, Rodrigues JL. Avaliação motora em educação física: teste ktk. 3. ed. São Paulo: Phorte; 2014.

14. Cohen J. Statistical power analysis for the behavioral sciences. Ed rev. New York: Academic Press, Inc (London); 1977.

15. Malak R, Kotwicka M, Krawczyk-Wasielewska A, Mojs SzamborskiW. Motor skills, cognitive development and balance functions of children with Down Syndrome. Ann Agricul Environ Med. 2013;20(4):803-6.

16. Silva MF, Kleinhans AC. Processos cognitivos e plasticidade cerebral na Síndrome de Down. Rev Bras Educ Espec. 2006;12(1):123-38.
17. Beqaj S, Tërshnjaku EE, Qorolli M, Zivkovic V. Contribution of physical and motor characteristics to functional performance in children and adolescents with Down Syndrome: a preliminary study. Med Sci Monit Basic Res. 2018;24: 159-67.

18. Deprá PP, Bisconsini CR, Vieira LF. Delay on gait patterns on Down Syndrome children. J Phys Educ. 2017;28:e2823.

19. Malak R, Kostiukow A, Krawczyk-Wasielewska A, Mojs E, Samborski W. Delays in Motor Development in Children with Down Syndrome. Med Sci Monitor. 2015;21:1904-10.

20. Pereira K, Basso RP, Lindquist AR, Silva LG, Tudella E. Infants with Down Syndrome: percentage and age for acquisition of gross motor skills. Res Devel Disabilities. 2013;34:894-901

21. Alesi M, Battaglia G, Pepi A, Bianco A, Palma A. Gross motor proficiency and intellectual functioning: a comparison among children with Down syndrome, children with borderline intellectual functioning, and typically developing children. Medicine (Baltimore). 2018;97(41):e12737.

22. Rintala P, Loovis EM. Measuring Motor Skills in finnish children with intellectual disabilities. Percept Mot Skills. 2013;116(1):294-303.

23. Agulló IR, González BM. Factores que influyen en el desarrollo motor de los niños con Síndrome de Down. Rev Med Inter Síndrome Down. 2006;10(2):18-24.

24. Oliveira CE, Salina ME, Annunciato NF. Fatores ambientais que influenciam a plasticidade do SNC. Acta Fisiátrica. 2001;8(1):6-13.

25. Arol P, Eroğlu KI. The effects of 8 week balance training on the kayaking performance of the beginners. Pedag Psychol, Med Biol Prob Phys Train Sports. 2018;22(4):170-5.

26. Wuang YP, Chiang CS, Su CY, Wang CC. Effectiveness of virtual reality using Wii gaming technology in children with Down Syndrome. Res Dev Disabil. 2011;32(1):312-21.

27. Pitetti K, Baynard T, Agiovlasitis S. Children and adolescents with Down Syndrome, physical fitness and physical activity. J Sport Health Sci. 2013;2(1): 47-57.

28. Costa VS, Silva HM, Azevêdo M, Silva AR, Cabral LL, Barros JF. Effect of hippotherapy in the global motor coordination in individuals with Down Syndrome. Fisioter Mov. 2017;30(Suppl 1):S229-40.

29. Pitetti K, Miller RA, Loovis EM. Balance and coordination proficiency of age-matched male and female children and adolescents with intellectual disabilities. Adapt Phys Activ Q. 2018;35(2):175-95.

30. Collet C, Folle A, Pelozin F, Botti M, Nascimento JV. Nível de coordenação motora de escolares da rede estadual da cidade de Florianópolis. Motriz. 2008;14(4):373-80. 